\title{
Proceeding
}

Performance Analysis Workshop, 2 - 5 April 2013, Alicante, Spain

\section{Determinants of competitive performance in rhythmic gymnastics. A review.}

\author{
MARTA BOBO-ARCE ${ }^{1}$, BELIA MÉNDEZ-RIAL² \\ ${ }^{1}$ University of A Coruña, A Coruña, Spain \\ 2 University of Vigo, Vigo, Spain
}

\begin{abstract}
Bobo-Arce M, Méndez-Rial B. Determinants of competitive performance in rhythmic gymnastics. A review. J. Hum. Sport Exerc. Vol. 8, No. Proc3, pp. S711-S727, 2013. Rhythmic Gymnastics is as a complex artistic and aesthetic sport with a particular training process and which demands high levels of physical and psychological stress in competition. Not many studies explain a good proposal which determinate the predictors of a competitive performance and a useful interaction-model of training and sport performance for the different context, ages and levels in rhythmic gymnastic. In this perspective, based on a critical examination of the literature about "Rhythmic Gymnastics" and "Performance", the aim of this research was to identify the factors that have been studied to predict a higher performance in Rhythmic Gymnastics, analyze them and determinate an "effectively training proposal" to achieve the higher results in competitions. We divided the references in different groups: a) Physiological and biological condition; b) Technical aspects; c) Psychological factors; d) Training process, e) Other dimensions and f) Performance analysis. The results show that most studies on rhythmic gymnastics are descriptive studies about a topic, fewer studies have examined one or more variables related with the performance and more scarce are the studies that show a global perspective and try to explain the predictor of the level of performance. In conclusion, we found some determinants of a competitive performance in Rhythmic Gymnastics which define our proposal. Further intervention studies and studies on the way of the Metamodel studies, "The theoretical and interaction of training and sport performance", would permit identify the contribution of each factor to the performance and would explain our model on a properly and scientifically way. Key words: HIGH PERFORMANCE, TRAINING PROCESS, TALENTS, SPORT.
\end{abstract}

\footnotetext{
Corresponding author. Belia Méndez Rial, Avda. Castrelos $2921^{\circ} 36210$ Vigo (Spain) +34 616122728

E-mail: beliamendez@hotmail.com

Performance Analysis Workshop, 2 - 5 April 2013, Alicante, Spain.

JOURNAL OF HUMAN SPORT \& EXERCISE ISSN 1988-5202

(C) Faculty of Education. University of Alicante

doi:10.4100/jhse.2013.8.Proc3.18
} 


\section{INTRODUCTION}

Rhythmic Gymnastics is as an artistic and aesthetic sport with a particular training process (very young athletes, earlier specialization before bone maduration, big volume of training, many hours of intensive training per week, lots of repetition, high level of technical elements performed, different abilities are required...). Moreover, high levels of physical and psychological stress are demanded in competition. The development of good rhythmic gymnasts requires an specific knowledge of the sport. Coaches, judges, gymnast or other staff involved in it do not have time to write the way of training and sometimes they do not want to explain it because there is competition. That is one reason why not many references are about this topic.

A quickly review of the literature show that some studies try to identify useful indicators for talent identification and development training plans but they explain separately each parameter: anthropometric characteristics (e.g. Di Cagno et al., 2008, Di Cagno et al., 2009 or Wang, 1989), physiological parameters (Di Cagno et al., 2013) or the explosive strenght (Douda et al., 2008). Hume (1993) explained some predictors of attainment in rhythmic sportive gymnastics (physical, psychological and training measures to performance of a sport) and Rutkauskaitè \& Skarbalius (2009), Rutkauskaite \& Skarbalius (2011) and Rutkauskaite \& Skarbalius (2012) established the preconditions of training optimization for 11 to 15 year old rhythmic gymnasts.

In general, we did not find a completely proposal which could identify the determinants of a competitive performance and a good interaction-model of training and sport performance for different context, ages and levels in rhythmic gymnastic (Illustration 1).

That is why, the aim of this research was to establish, through a critical examination of the literature about "Rhythmic Gymnastics", the factors that have been studied to predict a higher performance in Rhythmic Gymnastics. If we analyzed them, we could determinate an effectively training proposal to: a) Talent identification and development (TID); b) Improve and optimize the training process and c) Achieve the higher results in competition. It would we very usefull for all the protagonists involved in this sport (gymnasts, parents, coaches, judges, federation and technical staff, politicians, others).
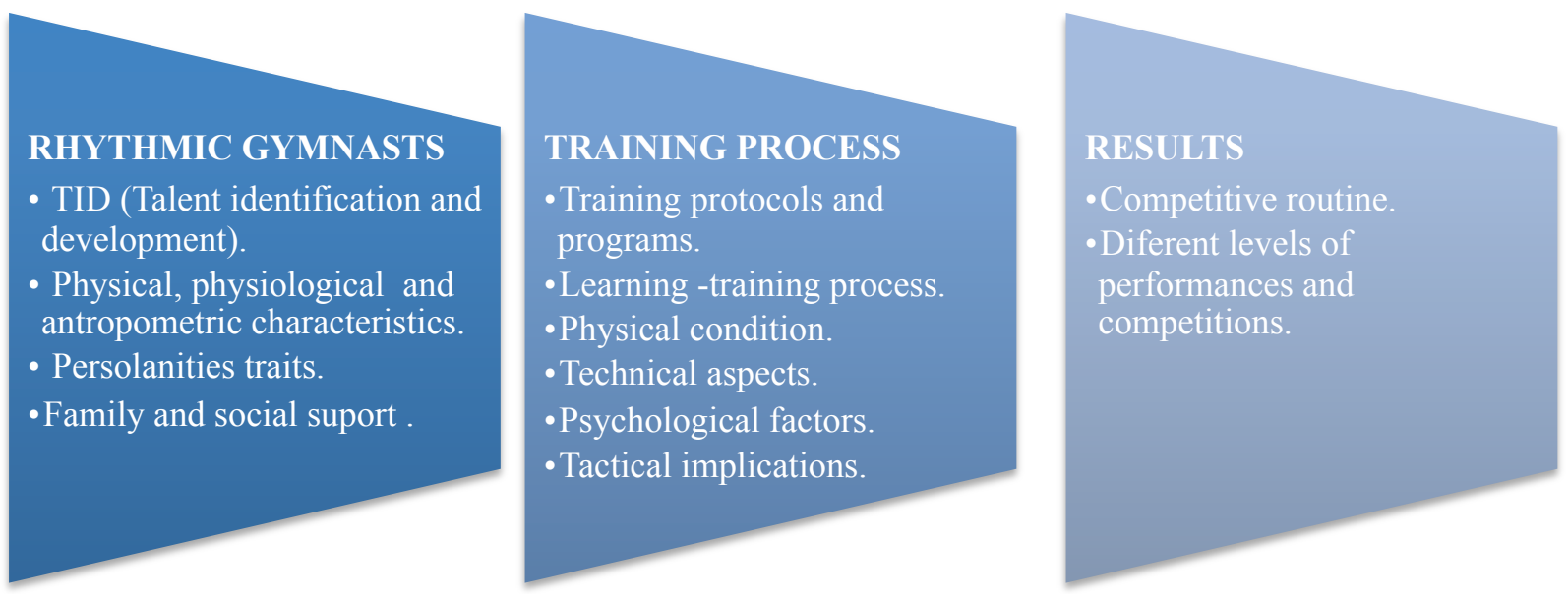

Figure 1. The Specific Context of Rhtythmic Gymnastics 


\section{MATERIAL AND METHODS}

Data sources and searches:

The following databases were searched: SportDiscus and PubMed the 15th of March 2013 (table 1). The coverage of both database are from 1949 until nowadays. After the combinations of key words entered with boolean opertor: "performance" and "rhythmic gymnastics" we found one hundred sixty-one references. SportDiscus had one hundred forty-seven references and PubMed twenty-eight. Fourteen studies were repeated. All other references were obtained from other citations but, we only included a hundred or references at the end of this article.

Table 1. Data base analyzed

\begin{tabular}{lll} 
Data base & SPORTDiscus & PubMed \\
\hline & Covers serial and monographic literature in & Includes over fourteen million citations for \\
& sport, recreation, exercise physiology, sports & biomedical articles back to the 1950's. These \\
Description & medicine, coaching, physical fitness, the & citations are from MEDLINE and additional life \\
& $\begin{array}{l}\text { psychology, history and sociology of sport, } \\
\text { training, and conditioning. Full text is available }\end{array}$ & $\begin{array}{l}\text { science journals. PubMed includes links to many } \\
\text { sites providing full text articles and other related } \\
\text { for } 550 \text { titles. }\end{array}$ \\
& From 1949 to 15th of March 2013 & From the 1950 to 15 $15^{\text {th }}$ of March 2013 \\
\hline Coverage & &
\end{tabular}

Selection of studies and analysis process:

Each reference we found was read (title, abstract, key words and the full text in the articles we found) and we analysed all of them acording to this five criteria:

1. Publication year: 1) before 1982; 2) from 1982 to 1991 ; 3) from 1992 to 2001 ; 4) from 2002 to 2011; 5) after 2011;

2. Type of reference: 2) Academic Journal; 2) Book; 3) Dissertation/Thesis, 4) Electronical resource/video recording; 5) Government document;

3. Topic of the study: 1) Physiological and biological condition; 2) Technical aspects; 3) Psychological factors; 4) Training process; 5) Other topics and 6) Performance analysis;

4. Point of view of the study: 1) Group 1: Descriptive studies of a topic, aspect or variable; 2) Group 2: Partial view, one or more aspects and the relationship with the performance and 3) Group 3: Whole view studies, the relationship between training and performance;

5. Other information: 1) Gender differences; 2) type of sample; 3) age of the gymnastics sample and 4) Level of the performance.

\section{RESULTS}

1. Publication year: One hundred and sixty references were analyze (Illustration 1). One of the studies did not have the year of publication. Most of the references $(78,8 \%)$ were publish between "1992 and 2011". From 2012 to 2011 was the decade with more references $(45,3 \%)$. 


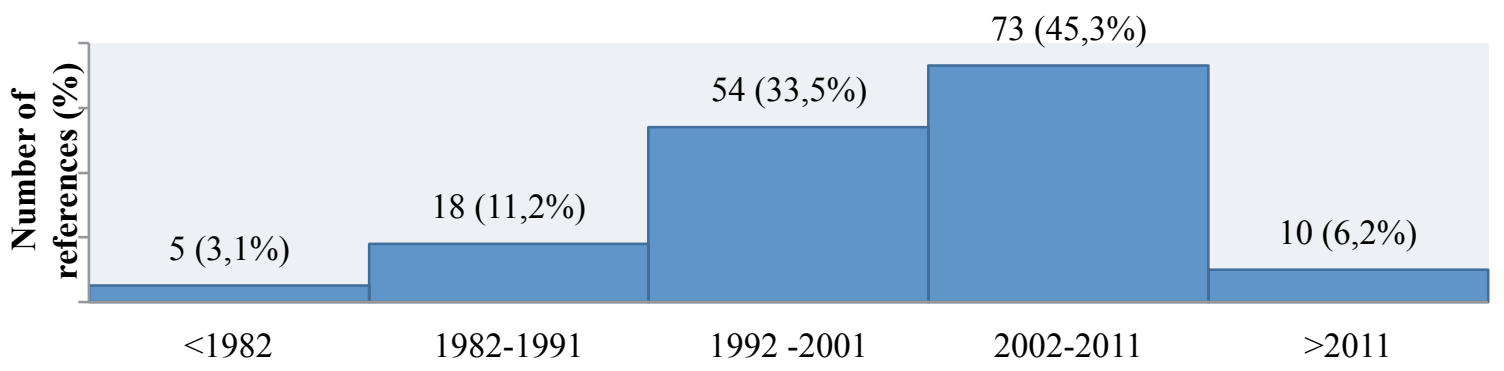

Figure 2. References "Rhythmic Gymnastics" AND "Performance" in SportDiscus and PubMed per year (15 th of March 2013)

2. Type of document: The "Academic Journal" was the most common type of references $(88,2 \%)$. Eleven references $(6,8 \%)$ were books and seven $(5 \%)$ were other type of document (Goverment document, eletronical recource, video recording or dissertation/thesis).

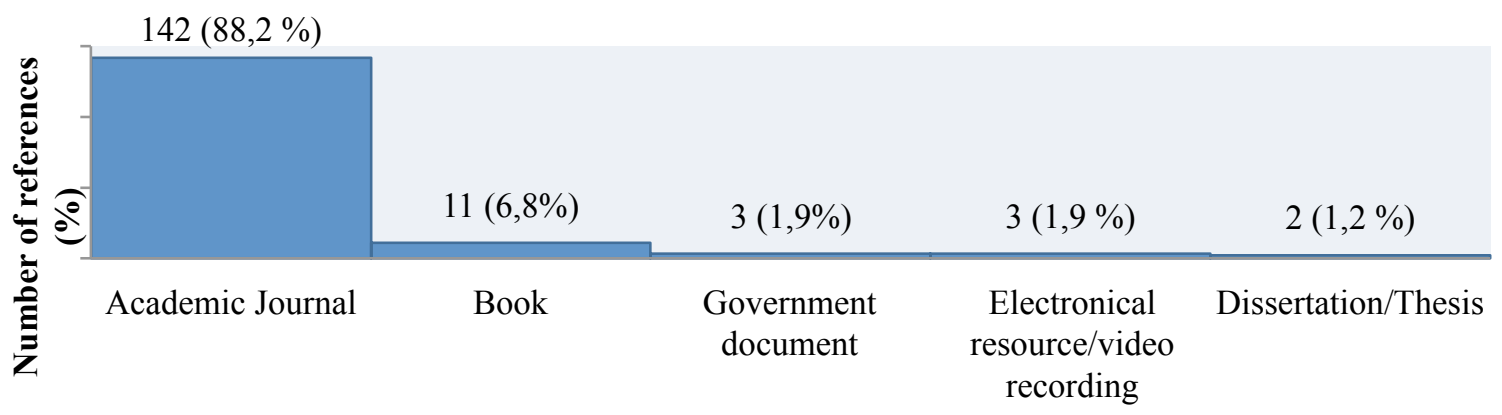

Figure 3. References "Rhythmic Gymnastics" AND "Performance" in SportDiscus and PubMed per type of document (15 th of March 2013)

3. Subject/ topic: Classifying the studies per topic, some of them included more than one topic. In general there were two hundred ninety-two topics. The analysis of the distributión of the topics (Illustration 4) explained that the $47,2 \%$ of the references were about technical aspects $(7,4 \%)$, twenty two about psychological factors $(8,2 \%)$, thirty-five related with the training process $(13 \%)$ and fifty about physical and biological condition (18,6\%) opposite to the $52,8 \%$ of the references which explain Performance (32\%) and Other topics $(20,8 \%)$.

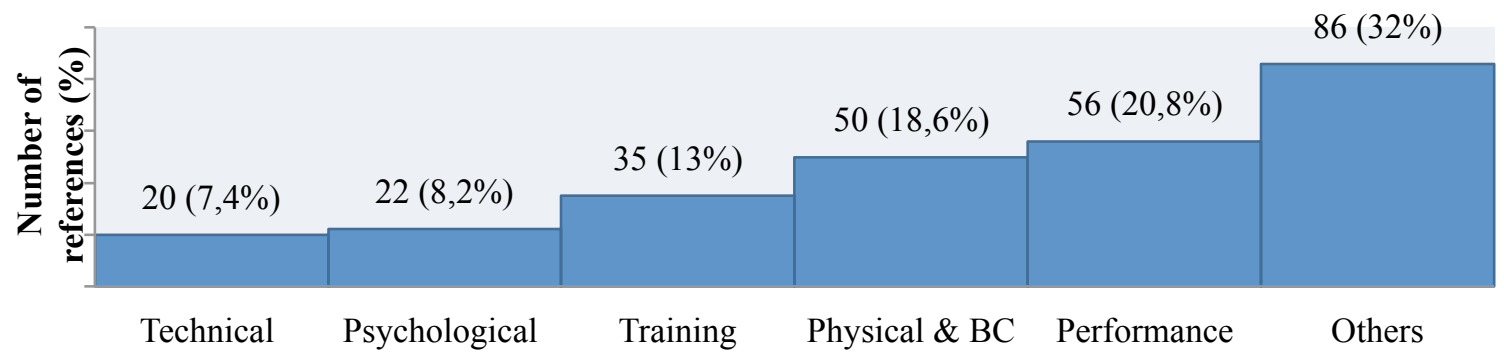

Figure 4. References "Rhythmic Gymnastics" AND "Performance" in SportDiscus and PubMed per topic (15 th of March 2013) 
Under each topic we found other dimensions analyzed.

3.1. Regarding the technical aspects, the dimensions analyzed (table 2) were five: apparatus, kinematic analysis, motor abilities, skills and technical elements. Jumps are the skills mostly studied (Di Cagno et al., 2008b; Di Cagno et al., 1995; Dyhre-Poulsen, 1987; Kums et al. 2005; Miletić et al., 2004b; Mkaouer et al., 2012; Özengin et al., 2011 and Purenović et al., 2010) and we did not found many studies about apparatus (Ávila-Carvalho et al. 2010; Ávila-Carvalho et al. 2011; Ávila-Carvalho et al. 2012 and Tsopani et al, 2012).

Table 2. Dimensions and studies about technical aspects

\begin{tabular}{|c|c|}
\hline Dimensions of analysis & References \\
\hline $\begin{array}{l}\text { Apparatus: Apparatus motor skills, apparatus } \\
\text { (ball), Apparatus difficulty group routine (roops, } \\
\text { hoop and clubs). }\end{array}$ & $\begin{array}{l}\text { Ávila-Carvalho et al. (2010), Ávila-Carvalho et al. (2011), Ávila- } \\
\text { Carvalho et al. (2012), Komanthi et al. (2012), Mkaouer et al. } \\
\text { (2012) and Tsopani et al. (2012). }\end{array}$ \\
\hline 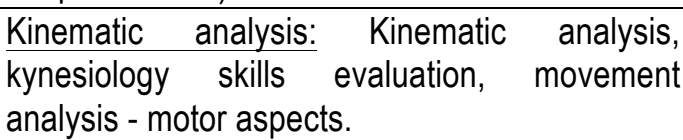 & Purenović et al. (2010) and Šebić-Zuhrić \& Smajlović (2009). \\
\hline $\begin{array}{l}\text { Motor abilities: Motor abilities, motor skills, basic } \\
\text { motor abilities. }\end{array}$ & $\begin{array}{l}\text { Kioumourtzoglou et al. (1997), Miletic et al. (1998), Miletić et al. } \\
\text { (2004b) and Šebić-Zuhrić \& Smajlović (2009). }\end{array}$ \\
\hline $\begin{array}{l}\text { Skills: Splits leaps (physiological recordings, } \\
\text { leaping performance) Leaping ability, Jumping } \\
\text { or leaping performance }\end{array}$ & $\begin{array}{l}\text { Dyhre-Poulsen (1987), Di Cagno et al (1995), Di Cagno et al. } \\
\text { (2008b), Mkaouer et al. (2012), Özengin et al. (2011), Purenović } \\
\text { et al. (2010), Kums et al. (2005) and Tsopani et al. (2012). }\end{array}$ \\
\hline 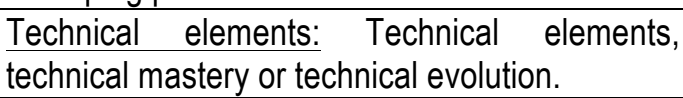 & $\begin{array}{l}\text { Buarque (2003), Bozanic and Miletic (2011) and Sekulic et al. } \\
(2002)\end{array}$ \\
\hline
\end{tabular}

3.2. Studies about psychology, explaines psychological dimensions in the higher performance (anxiety, attentional and pre-attentional process, self-consciousness); behaviour analysis (preceptual process, movement analysis); personality traits and other studies.

Table 3. Dimensions and studies about psychological factors

\begin{tabular}{|c|c|}
\hline Dimensions of analysis & References \\
\hline $\begin{array}{l}\text { Psychological dimensions in the higer } \\
\text { performance: } \\
\text { Attentional and pre-attentional process Anxiety } \\
\text { state on the performance, trait anxiety and } \\
\text { competitive state anxiety. } \\
\text { Self-consciousness or Self-efficacy. }\end{array}$ & $\begin{array}{l}\text { Daroglou (2011), Fan et al. (2004), Ferrand et al. (2002), Ferrand } \\
\text { \& Tedard (2001) and Tsopani et al. (2011). }\end{array}$ \\
\hline $\begin{array}{l}\text { Behaviour: } \\
\text { Preceptual process or perceptual and } \\
\text { cognitive abilities. Movement analysis - mental } \\
\text { aspects. }\end{array}$ & $\begin{array}{l}\text { Ermolaeva et al. (1998), Giannitsopulou et al. (2002), Hökelmann } \\
\text { et al. (2006), Kioumourtzoglou et al. (1997) and Li and Guo (2000). }\end{array}$ \\
\hline Personality traits: Personality. & Ferrand et al. (2005) \\
\hline $\begin{array}{l}\text { Others: Biofeedbak. Ethical implications for } \\
\text { the Sport psychologist. Job satisfaction } \\
\text { coaches. }\end{array}$ & $\begin{array}{l}\text { Drakou et al. (2008), Ferrand \& Tedard (2001), Johns (1993), } \\
\text { Peper \& Schmid (1983). }\end{array}$ \\
\hline
\end{tabular}

3.3. Training process was analysis from three points of view: perspective of the learning process, the specific training process and the itneraction between the training and the performance (table 4). 
Table 4. Dimensions and studies about training process

\section{Dimensions of analysis}

Learning process: teaching program, learning gymnastics skills, teaching systems, learnig.

Feedback, process correcting technical mistakes. RG Curriculum, Levels.

Training process: planning, methods, training cicle model, improving training levels, training volume, exercise training, problems, models. Precompetition warm-up, Pre-competition training and Competitive period.

Interaction between training (models) and Rutkauskaite (2005) and Rutkauskaitè \& Skarbalius (2012).

\section{References}

Cristina-Elena (2012), Gloucester (1993), Komanthi et al. (2012), Loquet (2011) and Tsopani et al. (2012)

Fang Huixin (1994), Fan et al. (2004b), Guiddeti et al. (2009), Hu (2001), Madelyn et al. (2008), Kroetenheardt (1989), Rutkauskaite (2005), Rutkauskaitė \& Skarbalius (2009), Rutkauskaite (2005), Rutkauskaitė \& Skarbalius (2011), Rutkauskaitė \& Skarbalius (2012), Sundgot-Borgen (1996) and Viru \& Smirnova (1995) performance.

3.4. The physical and biological condition is one of the topics mostly studied (table 5) on the way of: the anthropometric values, physical condition, physiological parameters and psychomotor dimensions.

\section{Table 5. Dimensions and studies about physical and biological condition}

\section{Dimensions of analysis}

Anthropometric values: Antrhopometric values, profile or characteristics. Somatic constitution, dynamic body equilibrium, body composition. Dermatologyfics, somatitype and morphological models. Growth and pubertal development.

Physical condition: Physical fitness, Physical aptitude characteristics.

Balance (vestibular system, body sway, postural strategies (postural trials) or control in lateral directions).

Stretching/ Static stretching.

Flexibility or general flexibility

Physiological parametres: physiological
characteristics, indices, determinants or respones.
Exhaustion, energy defits, maximal effort, energy
Organic prerequisites, heart-rate responses, blood
lactates, lipid profile and redox, ACE and AGTR1
polymorphisms.expenditure and rating perceived
exertition.

Psychomotor dimensions: Corporal language or Body conception. Spatial-temproal orientation. Coordination or situational motor-coordination. Rhythm perception, musical abilities or rhythmic ability. Latteral differenciation or homolateral hand and food.

\section{References}

Deutz et al. (2000), Quintero et al. (2011), Di Cagno et al. (2008), Di Cagno et al. (2008b), Douda et al. (2008), Georgopoulos et al. (1999), Menezes \& Filho (2006), Poliszczuk \& Broda (2010) and Wang (1989).

Beyer (1959), Calavalle et al. (2008), Di Cagno et al. (1995), Menezes \& Filho (2006), Napias (1997), Özengin et al. (2011) and Tsigilis et al. (1998).

Alexander et al. (1987), Bensar \& Steender (1989), Case et al. (1980), Deutz et al. (2000), Di Cagno et al. (2013), Douda et al. (1997), Douda et al. (2006), Douda et al. (2008), Guerra et al. (2001), Mihaela et al. (2012), Miletić et al. (2004), Polischuk, (2001) and Portier et al. (2006).

Antunes (1991), Capranica et al. (2005), Corat (2012), Fotiadou et al. (2006), Ma Xun (1993), Pavlidou et al. (2009), Penedo et al. (2006), Petkovic (2004), Popovic (2004), Soares (1981) and Wolf-Cvitak \& Starosta (2002). 
3.5. The performance analysis was very mentioned (table 6) with the aesthetic parameters; choreography process; the exercise (trends, visual model, knowledge or exercises); the predictors and results of the performance and the competitive success.

Table 6. Dimensions and studies about performance analysis

\begin{tabular}{|c|c|}
\hline Dimensions of analysis & References \\
\hline $\begin{array}{l}\text { Aesthetic parameters: Aesthetic competence } \\
\text { parameters, Artistic value }\end{array}$ & Ávila-Carvalho et al. (2008); Avila et al. (2011) \\
\hline $\begin{array}{l}\text { Choreography: choreography creation and } \\
\text { expresion }\end{array}$ & Nicklas et al. (1996) \\
\hline $\begin{array}{l}\text { Exercise: Rhythmic gymnastics exercises, } \\
\text { Trends or tendencies and analyses, Visual } \\
\text { model and knowledge of performance }\end{array}$ & $\begin{array}{l}\text { Gantcheva (1987), Magill \& Schoenfelder-Zohdi (1996), Sekulic et } \\
\text { al. (2002), Stefanova \& Yakimova (1987) and Wolf-Cvitak \& } \\
\text { Starosta (2002). }\end{array}$ \\
\hline $\begin{array}{l}\text { Predictors and results of the performance: } \\
\text { Determining elements of the performance, } \\
\text { factors influencing performance, predictor of } \\
\text { attainment, performance characteristics, } \\
\text { Sport performance, performance results, } \\
\text { Level of the performance (reliability). }\end{array}$ & $\begin{array}{l}\text { Di Cagno et al. (2009), Ferrando \& Tedard (2001), Hume et al. } \\
\text { (1993), Polischuk, T. (2001), Rutkauskaitè \& Skarbalius (2011) and } \\
\text { Rutkauskaitė \& Skarbalius (2012). }\end{array}$ \\
\hline Success: Success or competitive success. & Petkovic (2004) and Kroetenheardt (1989) \\
\hline
\end{tabular}

3.6. Other topics included different perspective about ryhtmic gymnastics associate with (table 7): appreciation of the beauty, computering support systems; sport context (socio-cultural, ethical implications, etc.); descriptive studies of rhythmic gymnastics and gymnasts; judge's process, medical supervision and gealth promotion focusing specially in eating disorders or talent identification.

Table 7. Dimensions and studies about other topics

\begin{tabular}{|c|c|}
\hline Dimensions of analysis & References \\
\hline Beauty: Apreciation of the beauty & $\mathrm{Li}(1999)$ \\
\hline Disability: deafness & Fotiadou et al. (2006) \\
\hline Informatics: Computer support system & Cuk et al. (1992) \\
\hline $\begin{array}{l}\text { Context: Socio-cultural, ethical implications } \\
\text { conditioning and gender differences, }\end{array}$ & Di Cagno et al. (2002) and Johns (1993). \\
\hline $\begin{array}{l}\text { Descriptive studies: evolution of performance, } \\
\text { teams, general information about rhythmic } \\
\text { gymnastics, sport, competition, interviews, } \\
\text { clinics. }\end{array}$ & $\begin{array}{l}\text { Bensar \& Steender (1989), Crumlis (2001), Crumlish (2005), FISU } \\
\text { (2003), Ho (1988), Kroetenheardt (1989), Kroetenheerdt \& Brzank } \\
\text { (1988), and Yi (2000). }\end{array}$ \\
\hline $\begin{array}{l}\text { Judges: Judge's process, evaluation criteria, } \\
\text { score, problems, computorized analysis, } \\
\text { coherent majority average, comparative } \\
\text { studies of judging or judgment of actions in } \\
\text { experts }\end{array}$ & $\begin{array}{l}\text { Babiloni et al. (2009), Bandettini \& Piazza (1985), Bormann (1988) } \\
\text { and Gianfranco \& Gaetano (2012). }\end{array}$ \\
\hline $\begin{array}{l}\text { Medical supervision and health promotion: } \\
\text { Medical supervision Nutritional needs, } \\
\text { nutitional behaviours, Eating disorders } \\
\text { (fasting \& festing, energy intake. }\end{array}$ & $\begin{array}{l}\text { Fang Huixin (1994), Gianfranco \& Gaetano (2012), Johns (1993), } \\
\text { Johns (1998), Vitali et al. (2003) and Sundgot-Borgen (1996). }\end{array}$ \\
\hline
\end{tabular}


\begin{tabular}{ll}
\hline Talent identification, development and & Di Cagno et al (2008), Di Cagno et al. (2008b), Di Cagno et al. \\
promotion. & (2009), Di Cagno et al. (2013) and Douda et al. (2008).
\end{tabular}

4. Point of view: In respect of the point of view, only four studies $(2,5 \%)$ explained a whole view about the relationship between training and performance [Group 3: Hume (1993), Rutkauskaitè \& Skarbalius (2009), Rutkauskaitė \& Skarbalius (2011) and Rutkauskaitė \& Skarbalius (2012)], thirty-one (19,3\%) explained the relationship between one or more aspects and the performance (Group 2), and all other references, hundred and twenty six $(78,3 \%)$ focused in a description of a topic, aspect or variable $(78,3 \%)$.

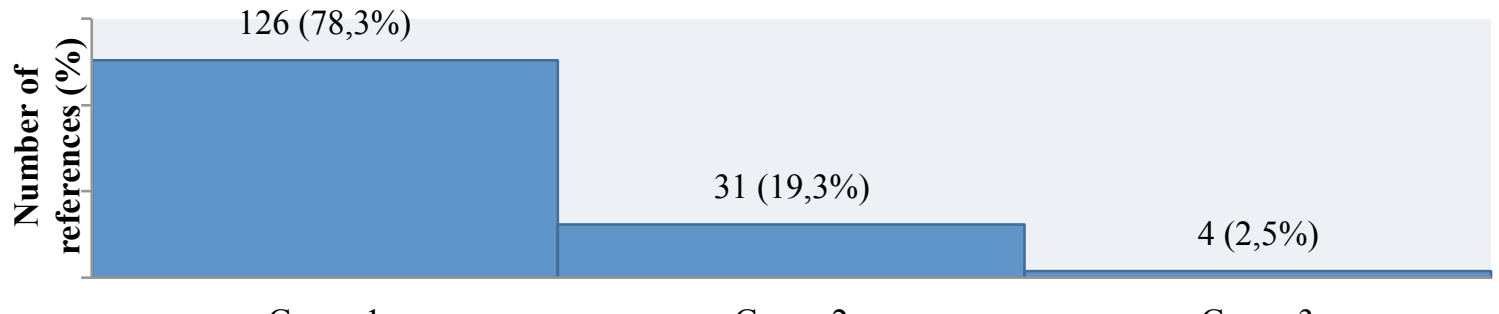

Group $1 \quad$ Group $2 \quad$ Group 3

Figure 5. References "Rhythmic Gymnastics" AND "Performance" in SportDiscus and PubMed per point of view (15 th of March 2013)

The review of the literature give us the information about that some studies started to identify and describe the determinants of a rhythmic gymnastics performance (Table 8). Some of them (Douda et al., 2008; Miletic et al., 2004; Di Cagno et al., 2009) explained only the relationship between antropometric and technical determinants of the rhytmic gymnastic performance. Others added the psychological factors and the training process in the first parametres (Hume, 1993; Rutkauskaite \& Skarbalius, 2009; Rutkauskaite \& Skarbalius, 2011; Rutkauskaite \& Skarbalius, 2012).

Table 8. Some studies about determinants of a rhythmic gymnastic performance

\begin{tabular}{|c|c|c|c|c|c|c|c|c|}
\hline Reference & Title & $\begin{array}{l}\text { Sample of rhythmic } \\
\text { gymnasts studied }\end{array}$ & $\mathbf{P}$ & P\&B & TC & PSY & TR & OF \\
\hline $\begin{array}{l}\text { Douda et al } \\
\quad(2008)\end{array}$ & $\begin{array}{l}\text { Physiological and anthropometric } \\
\text { determinants of rhythmic } \\
\text { gymnastic performance. }\end{array}$ & $\begin{array}{l}\quad n=34 \\
\text { elite }(n=15) \\
\text { no-elite }(n=19)\end{array}$ & $x$ & $x$ & & & & \\
\hline $\begin{array}{l}\text { Miletic et al } \\
(2004)\end{array}$ & $\begin{array}{l}\text { Some anthropologic factors of } \\
\text { performance in rhythmic } \\
\text { gymnastics novice }\end{array}$ & $\begin{array}{c}n=50 \\
\text { Age } 7.1+/-0.3 \text { years }\end{array}$ & $x$ & $x$ & $x$ & & & \\
\hline $\begin{array}{l}\text { Di Cagno et al. } \\
\qquad(2009)\end{array}$ & $\begin{array}{c}\text { Factors influencing performance } \\
\text { of competitive and amateur } \\
\text { rhythmic gymnastics-gender } \\
\text { differences }\end{array}$ & $\begin{array}{l}\quad n=24 \\
12 \text { male and } 12 \text { female } \\
\text { Age range } 22 \pm 4 \text { years }\end{array}$ & $x$ & $x$ & $x$ & & & \\
\hline Hume (1993) & $\begin{array}{l}\text { Predictors of attainment in } \\
\text { rhythmic sportive gymnastics }\end{array}$ & $\begin{array}{l}\quad n=106 \\
\text { Aged } 7-27 \text { years }\end{array}$ & $x$ & $x$ & $x$ & $x$ & $x$ & $x$ \\
\hline $\begin{array}{l}\text { Rutkauskaite \& } \\
\text { Skarbalius } \\
\text { (2009) }\end{array}$ & $\begin{array}{c}\text { Training and sport performance of } \\
\text { the } 11-12 \text { years old athletes in } \\
\text { rhythmic gymnastics }\end{array}$ & $\begin{array}{c}n=25 \text { National gymnasts } \\
\text { Age } 11-12 \text { year old }\end{array}$ & $x$ & $x$ & $x$ & $x$ & $x$ & $x$ \\
\hline
\end{tabular}




\begin{tabular}{|c|c|c|c|c|c|c|c|c|}
\hline Reference & Title & $\begin{array}{l}\text { Sample of rhythmic } \\
\text { gymnasts studied }\end{array}$ & $\mathbf{P}$ & P\&B & $\mathrm{TC}$ & PSY & TR & OF \\
\hline $\begin{array}{c}\text { Rutkauskaite \& } \\
\text { Skarbalius } \\
\text { (2011) }\end{array}$ & $\begin{array}{l}\text { Interaction of training and } \\
\text { performance of } 13-14 \text { year old } \\
\text { athletes in rhythmic gymnastics }\end{array}$ & $\begin{array}{c}n=15 \text { National gymnasts } \\
\text { Age } 13-14 \text { year old }\end{array}$ & $x$ & $x$ & $x$ & $x$ & $x$ & $x$ \\
\hline $\begin{array}{l}\text { Rutkauskaite \& } \\
\text { Skarbalius } \\
\text { (2012) }\end{array}$ & $\begin{array}{l}\text { Models and interaction of } \\
\text { intensive training and sport } \\
\text { performance of } 14-15 \text { years old } \\
\text { athletes in rhythmic gymnastics. }\end{array}$ & $\begin{array}{l}n=10 \text { National gymnasts } \\
\text { Age } 14-15 \text { year old }\end{array}$ & $x$ & $x$ & $x$ & $x$ & $x$ & $x$ \\
\hline
\end{tabular}

*Note: $\mathrm{P}=$ Performance; $\mathrm{P \& B}=$ Physical and Biological Condition; $\mathrm{TC}=$ Technical aspects; $\mathrm{PSY}=$ Psychological factors; $\mathrm{TR}=$ Training process; $\mathrm{OF}=$ others factors.

5. Other information: A part from the four aspects we analyze in this article [1), Publication year, 2) Type of reference, 3)Topic of the study, 4) Point of view] other dimensions have been studied and included in the tittle of the reference: gender differences, type of sample, age of the gymnasts or level of the performance. The aspects analyze were:

5.1. Gender differences: in amateur rhythmic gymnastics (Di Cagno et al., 2009) or related with technical mastery (Bozanic \& Miletic, 2011).

5.2. Type of sample: Gymnasts and runners (Deutz et al., 2000); artistic and modern rhythmic gymnastics (Bormann, 1988); gymnasts and no gymnasts (Pavlidou et al., 2009); artistic and rhythmic female gymnasts (Douda et al., 1997); coaches (Drakou et al., 2008); judges (Gianfranco \& Gaetano, 2012); experts (Babiloni et al., 2009); teams (Bensar \& Steender, 1989; Case et al., 1980; Fang Huixin, 1994; Yi, 2000) or Recognized Gymnasts: Irina Superestar (FISU, 2003); Inna Zhukova (Crumlish, 2005); Irina Chaschina (Crumlish, 2001).

5.3. Age of the gymnastics sample: children (Cuk et al., 1992); children with deafness (Fotiadou et al., 2006); infantile and pre-infantile rhythmic gymnastics (Penedo et al., 2006); rhythmic gymnastics novices (Miletic et al., 2004); youth age (Di Cagno et al., 2002); teenagers female gymnasts (Guerra et al., 2001); college women (Beyer, 1959); Female sport students (Ferrand et al., 2002; Ferrand et al., 2005); Rhythmic gymnasts girls (Poliszczuk \& Broda, 2010); young female rhythmic gymnasts (Tsopani et al., 2011); 11 to 12 years old athletes in rhythmic gymnastics (Rutkauskaite \& Skarbalius, 2009); 13 to 14 years old athletes in rhythmic gymnastics (Rutkauskaitè \& Skarbalius, 2011) or 14 to 15 years old athletes in rhythmic gymnastics (Rutkauskaitè \& Skarbalius, 2012) or older women (Capranica et al., 2005).

5.4. Level of the performance: female gymnasts from different qualification levels (Menezes \& Filho, 2006); amateur rhythmic gymnasts (Di Cagno et al., 2008); national gymnasts (Fang Huixin, 1994); sub-elite gymnasts (Guidetti et al., 2009); elite female gymnasts (Ávila-Carvalho et al. 2010; Deutz et al., 2000; Di Cagno et al., 1995; Di Cagno et al., 2008; Georgopoulos et al. 1999; Guidetti et al., 2009); Top level rhythmic gymnasts (Fan et al., 2004) or World and European rhythmic gymnastics (Bandettini \& Piazza, 1985).

\section{DISCUSSION}

The results are similar to other researches, which have mentioned that not many studies explain a proposal of the determinants a competitive performance in Rhythmic Gymnastics (Hume, 1993). 
We identify some studies which explain the predictors of a high performance in rhythmic gymnastics through a whole perspective (Illustration 6) and in which training and performance are related (Hume, 1993;

Rutkauskaite \& Skarbalius, 2009; Rutkauskaite \& Skarbalius, 2011; Rutkauskaite \& Skarbalius, 2012) and other studies which explain some predictors such as anthropometric characteristics, physical condition or technical aspects of a competitive performance separately (Douda et al., 2008, Miletic et al., 2004; Di Cagno et al., 2009).

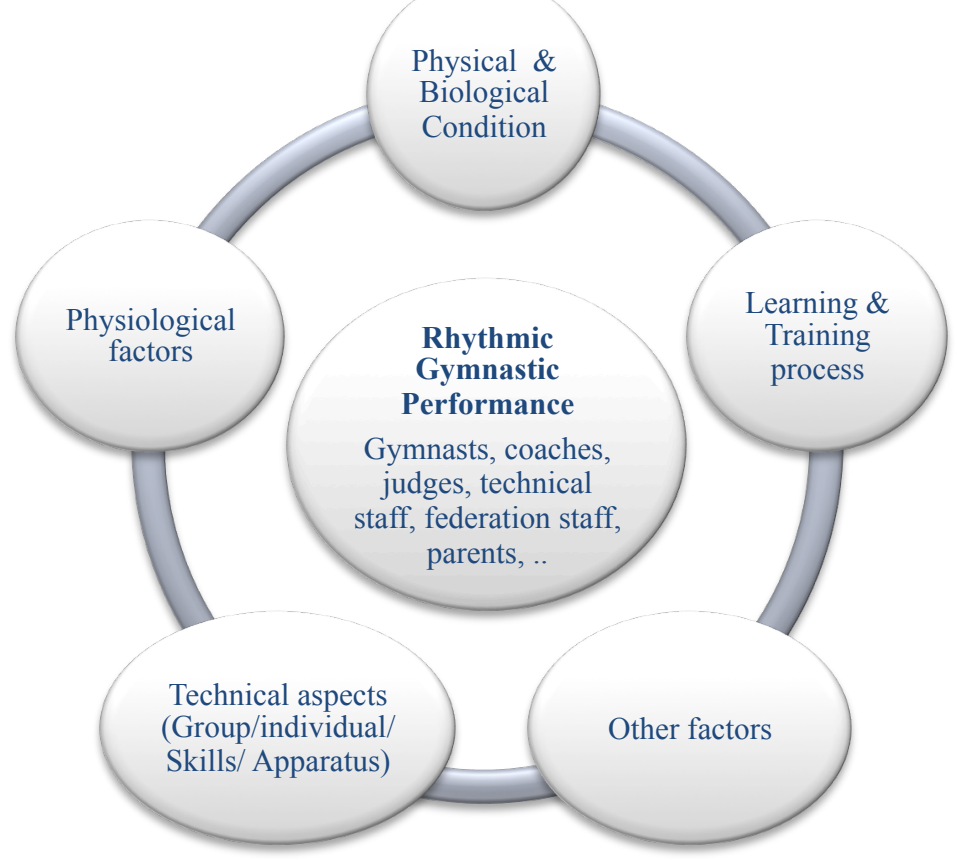

Figure 6. Dimensions of a competitive performane in the specific context of the Rhythmic Gymnastis

Researches has not established models of training and sport performance (as well as their interaction) of rhythmic gymnastics athletes of different ages and sport performance levels (basic and special) (Rutkauskaite \& Skarbalius, 2009; Rutkauskaite \& Skarbalius, 2011; Rutkauskaite \& Skarbalius, 2012).

Like other authors have explained (Di Cagno et al., 2008; Di Cagno et al., 2008b; Di Cagno et al., 2009; Di Cagno et al., 2013; Douda et al., 2008) if we verified which parameters are useful indicator and their contribution to a successful performance rhythmic gymnastics, we could have a guideline for talent identification, selection, development and promotion.

In general, the line of investigation needs to continue because it is not enough to understand and have a useful and empirical proposal of "training and sport performance" based on the theory and apply in the practice in the specific context of rhythmic gymnastics (Illustration 7).

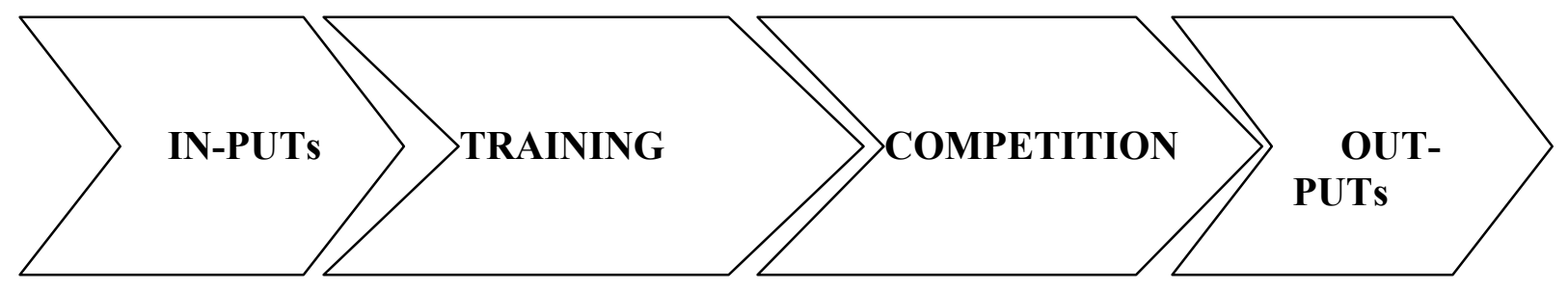

Figure 7. Interaction model of training-sport performance in competition in rhythmic gymnastics 


\section{CONCLUSIONS}

After the analysis of more than a hundred of references about Rhythmic Gymnastics and Performance from two data bases here are the conclusions:

1. The digital references are increasing in the Database every year since 1982, a good sign of applied new technologies in sport.

2. The most common type of document still being Academic Journal something not new because we analyze two digital database but it is a good symptom of the investigation in rhythmic gymnastics. We found other types of document but in less number (Books, Government document, electronical resource/video recording and Dissertation/Thesis).

3. Most studies were descriptive studies about a topic $(78,3 \%)$, fewer studies have examined one or more variables related to the performance $(19,3 \%)$ and more scarce are the studies which show a global perspective and try to explain the predictor of the level of performance (2,5\%) (Hume et al, 1993; Rutkauskaita and Skarbalius, 2009; Rutkauskaita and Skarbalius, 2011; Rutkauskaita and Skarbalius, 2012).

4. The usual topics studied were: the Performance $(32 \%)$, Physical Condition \& Biological aspects $(18,6 \%)$ and training process $(13 \%)$. Psychological $(8,2 \%)$, technical aspects $(7,4 \%)$ and other studies $(20,5 \%)$ were the other topic studied.

5. Some dimensions of a competitive performance in Rhythmic Gymnastics which define part of a future proposal were found. Some of the dimensions are: a) Technical aspects (Aparatus, kinematic analysis, motor abilities and skills and technical elements); b) Psychological factors (Psychological dimensions in high performance, behavior analysis, personality traits and other factors); c) Training process (Learning, training, interaction between training and performance); d) Physical and biological condition (anthropometric values, physical condition, physiological parameters, psychomotor dimensions); e) Performance analysis (aesthetic parameters, choreography, exercise, predictors and results of the performance, success) and f) Other factors (beauty, informatics, context, descriptive studies, judge's process, medical supervision and health promotion, talent identification; others).

6. This study suggested that is necesary increse the research in this area. Some implications were found (Illustration 8) but further research could explain the determinants of competitive performance in rhythmic gymnastics and an interacion model of training - competition for diferent context, ages and levels in rhythmic gymnastics. 


\section{This study explain a ritical examination of the literature about}

Rhythmic Gymnastics \& Performance in two data base:

- Scare studies show a global perspective and try to explain the predictors of performance.

- Some predictors of a competitive performance in Rhythmic Gymnastics were founded.

Further research could explain:

- The determinants of competitive performance in rhythmic gymnastics.

- Interaction Training \& competition model for different context, ages and levels in rhythmic gymnastic.

Figure 8. Implications and conclusions of this study

\section{REFERENCES}

1. ALEXANDER MJL, BORESKIE SR, LAW S. Heart-rate response and time motion analysis of rhythmic sportive gymnastics. Journal of Human Movement Studies. 1987; 13 (9): 473-489.

2. ANTUNES MR. A concepcao de corpo na ginastica ritmica desportiva. Rio de Janeiro: Universidade Gama Filho. 1991

3. ÁVILA-CARVALHO L, KLENTROU P, LEBRE E. Handling, Throws, catches and collaborations in elite group rhythmic gymnastics. Science of Gymnastics Journal. 2012; 4 (3): 37-47.

4. ÁVILA-CARVALHO L, LEBRE E, PALOMERO ML. Study of the Artistic Value of the Group Exercises at the Portimão Rithmic Gymnastics World Cup in 2007 and 2008. Apunts: Educació Física i Esports. 2011; 103 (1): 68-75.

5. ÁVILA-CARVALHO L, PALOMERO M, DA L, LEBRE E. Apparatus difficulty in groups routines of elite rhythmic gymnastics at the Portimão 2009 World cup series. Science of Gymnastics Journal. 2010; 2 (3): 29-42.

6. BABILONI C, DEL PERCIO C, ROSSINI PM, MARZANO N, IACOBONI M, INFARINATO F, LIZIO R, PIAZZA M, PIRRITANO M, BERLUTTI G, CIBELLI G, EUSEBI F. Judgment of actions in experts: a high-resolution EEG study in elite athletes. Neuroimage. 2009; 45 (2): 512-521.

7. BANDETTINI L, PIAZZA M. Computerized analysis and critical evaluation of the world and european rhythmic sporting gymnastics from 1977 to 1984. Gymnica. 1985; 1: 18-23.

8. BENSAR E, STEENDER G. On selected organic prerequisites for female athletes of the national team in rhythmic sportive gymnastics. Theorie und Praxis des Leistungssports, 1989; 27 (8/9): 131-135.

9. BEYER B. Effects of rhythmic gymnastics on the physical fitness of college women. (Doctoral Dissertation). Available from Microform Publications, International Institute for Sport and Human Performance, University of Oregon; 1959.

10. BORMANN G, Problems concerning evaluative criteria of the sport movements aestethics in artistic and modern rhythmic gymnastics. Gymnica. 1988; 2: 2-7. 
11. BOZANIC A, MILETIC D. Differences between the sexes in technical mastery of rhythmic gymnastics. Journal of Sports Sciences. 2011; 29 (4): 337-343.

12. BUARQUE MAAG. General gymastics at Manguiera's social program: the importance of the "technical evolution" aspect. Fitness \& Performance Journal (Online Edition). 2003; 2 (4): 252.

13. CALAVALLE AR, SISTI D, ROCCHI MBL, PANEBIANCO R, DEL SAL M, STOCCHI V. Postural trials: expertise in rhythmic gymnastics increases control in lateral directions. European Journal of Applied Physiology. 2008; 104 (4): 643-649.

14. CAPRANICA L, TESSITORE A, OLIVIERI B, PESCE C. Homolateral hand and foot coordination in trained older women. Gerontology. 2005; 51 (5): 309-315.

15. CASE S, FECK S, KOEHLER P. Physiological and performance characteristics of the 1979 U.S. MRG team. International Gymnast. 1980; 22 (4): 10-11.

16. CORAT L, BETTINE DE ALMEIDA MA. Análise da concepção de corpo na Ginástica rítmica: um estudo dos manuais 1932 a 1958. Revista de História do Esporte. 2012; 5 (1): 01-26.

17. CRISTINA-ELENA M. Feedback in rhythmic gymnastics as a process of correcting technical mistakes. Sport \& Society. 2012; 12 (2): 149-151.

18. CRUMLISH J. Good sport: integrity and passion typify the performances of Irina Chaschina. International Gymnast. 2001; 43 (8/9): 35.

19. CRUMLISH J. Inna Zhukova Renews Olympic Vow. International Gymnast. 2005; 47 (4): 23.

20. CUK I, NOVAK D, BOLKOVIC T, VAJNGERI B. A computer supported system of primary selection of children in sports gymnastics. Kinesiologia Slovenica. 1992; 1 (1): 27-31.

21. DAROGLOU G. Coping Skills and Self-efficacy as Predictors of Gymnastic Performance. Sport Journal. 2011; 14 (1): 1.

22. DEUTZ RC, BENARDOT D, MARTIN DE, CODY MM. Relationship between energy deficits and body composition in elite female gymnasts and runners. Medicine Science Sports Exercise. 2000; 32 (3): 659-668.

23. DI CAGNO A, BALDARI C, BATTAGLIA C, GALLOTA MC, VIDEIRA M, PLAZZA M, GUIDEVTTI $L$. Preexercise staticc stretching effect on leaping performance in elite rhythmic gymnastics. Journal of Strength \& Conditioning Research. 2010; 24 (8): 1995-2001.

24. DI CAGNO A, BALDARI C, BATTAGLIA C, GUIDETTI L, PIAZZA M. Anthropometric characteristics evolution in elite rhythmic gymnasts. Ital J Anat Embryol. 2008; 113 (1): 29-35.

25. DI CAGNO A, BALDARI C, BATTAGLIA C, BRASILI P, MERNI F, PIAZZA M, TOSELLI S, VENTRELLA AR, GUIDETTI L. Leaping ability and body composition in rhythmic gymnasts for talent identification. J Sports Med Phys Fitness. 2008; 48 (3): 341-346.

26. DI CAGNO A, BALDARI C, BATTAGLIA C, MONTEIRO MD, PAPPALARDO A, PIAZZA M, GUIDETTI L. Factors influencing performance of competitive and amateur rhythmic gymnasticsGender differences. Journal of Science \& Medicine in Sport. 2009; 12 (3): 411-417.

27. DI CAGNO A, SAPERE N, PIAZZA M, AQUINO G, IULIANO E, INTRIER M, CALCAGNO G. ACE and AGTR1 polymorphisms in elite rhythmic gymnastics. Genet Test Mol Biomarkers. 2013; 17 (2): 99-103.

28. DI CAGNO A, VITALI S, PANTANELLI R, TODINI S, DI FILIPPO R. Rhythmic gymnastic for youth age: socio-cultural conditioning and gender differences. In Koskolou, M. (Ed.), European College of Sport Science, Proceedings of the 7th annual congress of the European College of Sport Science, Athens, Greece, 24-28 July 2002, 736. Athens, Pashalidis: Medical Publisher.

29. DOUDA H, AVLONITI A, KASABALIS A, SMILIOS I, TOKMAKIDIS, SP. Application of Ratings of Perceived Exertion and Physiological Responses to Maximal Effort in Rhythmic Gymnasts. International Journal of Applied Sports Sciences. 2006; 18 (2): 78-88. 
30. DOUDA H, TOUBEKIS AG, AVLONITI A, TOKMAKIDIS SP. Physiological and Anthropometric Determinants of Rhythmic Gymnastics Performance. International Journal of Sports Physiology \& Performance. 2008; 3 (1): 41-54.

31. DOUDA H, TOKMAKIDIS SP, PILIANIDIS T. Comparative study of physical performance characteristics between rhythmic sports gymnasts and female artistic gymnasts. AIESEP. World Conference on Teaching, Coaching and Fitness Needs in Physical Education and the Sport Sciences. Proceedings, School of Physical Education, 269-275. Singapore, 1997.

32. DRAKOU A, HARAHOUSSOU Y, KABITSI N, TZETZIS G. Job Satisfaction Differences among Coaches of Various Sports in Greece. Inquiries in Sport \& Physical Education. 2008; 6 (1): 1-14.

33. DYHRE-POULSEN P. An analysis of splits leaps and gymnastic skill by physiological recordings. European Journal of Applied Physiology \& Occupational Physiology. 1987; 56 (4): 390-397.

34. ERMOLAEVA MV, ERMOLAEV BV, CIKOVA MM. Attentional and pre-attentional processes in rhythmic gymnastics. SDS: Rivista di Cultura Sportiva. 1998; 17 (41/42): 91-96.

35. FAN L, CAO C, TANG $\mathrm{H}$. Influence of anxiety state on the performance stability of top-level rhythmic gymnasts. In Klisouras, V. (ed.). Pre-olympic congress: proceeding: Volumen Il: Posters: Sport Science through the ages. 06-11 august 2003, 23-24. Thessaloniki, Greece: Aristotle University of Thessaloniki, Department of Physical Education \& Sport Science. 2004.

36. FAN, L., TANG, H. \& ZHAO, Y. Problems in the training of Chinese rhythmic gymnasts. In Klisouras, V. (ed.). Pre-olympic congress: proceeding: Volumen II: Posters: Sport Science through the ages, 06-11 august 2003, 68-70. Thessaloniki, Greece: Aristotle University of Thessaloniki, Department of Physical Education \& Sport Science. 2004b.

37. FANG HUIXIN. Discussion on medical supervision over the pre-competition training of national rhythmic gymnastics team. Sports Science/Tiyu Kexue. 1994; 14 (1): 78-82.

38. FERRAND C, CHAMPELY S, TETARD S. Relationships between trait anxiety, self-esteem and self-handicapping strategies in female sport students involved in a French national exam. STAPS: Revue des Sciences \& Techniques des Activites Physiques \& Sportives automne. 2002; 23 (59): 89-100.

39. FERRAND C, CHAMPELY S, BRUNEL, PC. Relations between female students' personality traits and reported handicaps to rhythmic gymnastics performance. Psychol Rep. 2005; 96 (2): 361-373.

40. FERRANDO C, TEDARD $S$. Priate self-consciousness, a determining element of the performance. SDS: Rivista di Cultura Sportiva. 2001; 20 (52): 49-56.

41. FISU. Irina superstar. FISU Magazine. 2003: 58; 26-29.

42. FOTIADOU EG, TSIMARAS VK, GIAGAZOGLOU PF, SIDIROPOULOU MP, KARAMOUZI AM, ANGELOPOULOU NA. Effect of rhythmic gymnastics on the rhythm perception of children with deafness. Journal of Strength Conditioning Research. 2006; 20 (2): 298-303.

43. GANTCHEVA G. XIIlth World Championship in Rhythmic Gymnastics - Trends, tendencies and analyses. Treniorska Misal. 1987; 12: 11-16.

44. GEORGOPOULOS N, MARKOU K, THEODOROPOULOU A, PARASKEVOPOULOU P, VARAKI L, KAZANTZI Z, LEGLISE, M. \& VAGENAKIS, AG. Growth and pubertal development in elite female rhythmic gymnasts. Journal Clin. Endocrinol Metab. 1999; 84 (12): 4525-4530.

45. GIANFRANCO I, GAETANO P. Anti-collusion indices and averages for the evaluation of performances and judges. Journal of Sports Sciences. 2012; 30 (4): 411-418.

46. GLOUCESTER O. Rhythmic gymnastics: NCCP levels 1 - 3 curriculum. Canadá: Canadian Rhythmic Sportive Gymnastic Federation. 1993.

47. GUERRA A, REGO C, LAIRES MJ, CASTRO EM, SILVA D, MONTEIRO C, SILVA Z, LEBRE E, $\mathrm{BICHO}$ M. Lipid profile and redox status in high performance rhythmic female teenagers gymnasts. Journal of Sports Medicine \& Physical Fitness. 2001; 41 (4): 505-512 
48. GUIDETTI L, CAGNO AD, GALLOTTA MC, BATTAGLIA C, PIAZZA M, BALDARI C. Precompetition warm-up in elite and subelite rhythmic gymnastics. Journal of Strength \& Conditioning Research. 2009; 23 (6): 1877-1882.

49. HO K. High performance rhythmic sportive gymnastics. Part 1. Gymnastics Coach. 1988; 7 (1): 15-17.

50. HU XF. How to improve the training level for art gymnastics in China. Journal of Hubei Sports Science. 2001; 20 (1): 38-39.

51. HUME PA, HOPKINS WG, ROBINSON DM, ROBINSON SM, HOLLINGS SC. Predictors of attainment in rhythmic sportive gymnastics. Journal of Sports Medicine \& Physical Fitness. 1993; 33 (4): 367-377.

52. JOHNS D. Fasting and feasting: paradoxes of the sport ethic. Sociology of Sport Journal. 1998; $15(1): 41-63$.

53. JOHNS D. Nutritional need or athletic over conformity: ethical implications for the sport psychologist. Sport Psychologist. 1993; 7 (2): 191-203.

54. KIOUMOURTZOGLOU E, DERRI V, MERTZANIDOU O, TZETZIS G. Experience with perceptual and motor skills in rhythmic gymnastics. Perceptual \& Motor Skills. 1997; 84 (3): 1363-1372.

55. KOMANTHI K, THEODOSIS E, APOSTOLOS, S. Eating disorders in the world of sport: the experiences of rhythmic gymnasts. Biology of Exercise. 2012; 8 (2): 19.

56. KROETENHEARDT M. Evaluation of performance in rhythmic sportive gymnastics from 1985 to 1988 on the basis of a training cycle model. Theorie und Praxis des Leistungssports. 1989; 27 (8/9): 36-45.

57. KROETENHEERDT M, BRZANK R. On the performance development in rhythmic sportive gymnastics. Theorie und Praxis des Leistungssports. 1988; 26 (10): 108-124.

58. KUMS T, ERELINE J, GAPEYEVA H, PAASUKE M. Vertical Jumping performance in young rhythmic gymnasts. Biology of Sport. 2005; 22 (3): 237-246.

59. LI W. On the beauty of rhythmic gymnastics and its appreciation. Journal of Wuhan Institute of Physical Education. 1999; 2: 55-58.

60. LI WD, GUO XY. A primary study on structural characteristics of event related cognitive ability of elite rhythmic gymnasts. Journal of Wuhan Institute of Physical Education. 2000; 34 (6): 101-104.

61. LOQUET M. Knowledge-in-action between rules and experiences: lessons from high performance sport for physical education. Physical Education \& Sport Pedagogy. 2011; 16 (2): 145-162.

62. MA XUN. Creation of music for rhythmic sportive gymnastics. Journal of Beijing Sport University. 1993; 16 (4): 30-34.

63. MAGILL RA, SCHOENFELDER-ZOHDI B. A visual model and knowledge of performance as sources of information for learning a rhythmic gymnastics skill. International Journal of Sport Psychology. 1996; 27 (1): 07-22.

64. MADELYN P, COTE J, ANDERS ERICSSON K. Characteristics of expert development in rhythmic gymnastics: A retrospective study. Sport and Exercise Psychology. 2007; 5 (1): 82-103.

65. MATHYS N, MEYER EGIL C, MATTER S, BIEDERT R, BIRKHAEUSER M. Retrospective questionnaire on Female Athlete Triad for Swiss female athletes. Sportmedizin \& Sporttraumatologie. 2005; 53 (4), 167-171.

66. MENEZES LS, FILHO JF. Identification and comparison of dermatologics somatoglyfics, somatotype and basic physical aptitude characteristics of rhythmic gymnasts of different qualification levels. Fitness \& Performance Journal (Online Edition). 2006; 5 (6): 47.

67. MIHAELA M, VASILICA G, LAVINIA P. Study about the energy expenditure assessment in rhythmic gymnastics. Science, Movement \& Health. 2012; 12 (2): 170-175. 
68. MILETIĆ D, SEKULIÉ D, WOLF-CVITAK J. The leaping performance of 7-years-old novice rhythmic gymnasts is highly influenced by the condition of their motor abilities. Kinesiology. 2004b; 36 (1): 35-43.

69. MILETIĆ D, KATIĆ R, MALES B. Some anthropologic factors of performance in rhythmic gymnastics novices. Coll Antropol. 2004; 28 (2): 727-737.

70. MILETIC D, SRHOJ L, BONACIN D. The impact of the initial status of motor abilities on mastering motor proficiency in rhythmic sports gymnastics. Kinesiology. 1998; 30 (2): 66-76.

71. MKAOUER B, AMARA S, TABKA Z. Split leap with and without ball performance factor in rhythmic gymnastics. Science of Gymnastics Journal. 2012; 4 (2): 75-81.

72. NAPIAS F. Performance factors - flexibility: illustration in rhythmic gymnastics. EPS Education Physique \& Sport. 1997; 46 (265): 50-52.

73. NICKLAS I, WERNER S, SCHIMAK H, BRAEUNIG K. Observation results to the performance characteristic features choreography/creation and expression in rhythmic sportive gymnastics competitions. Leipziger Sportwissenschaftliche Beitraege. 1996; 37 (1): 84-94.

74. ÖZENGIN N, ÜN YILDRIM N, BALTACI G, MASIULIS N. Acute effects of different stretching duration on vertical jump performance in rhythmic gymnasts. Education Physical Training Sport. 2011; 3 (83): 16-22.

75. PAVLIDOU E, MERTZANIDOU O, ZISI V. Evaluation of Rhythmic Ability in Rhythmic Gymnasts and Non Gymnasts. Inquiries in Sport \& Physical Education. 2009; 7 (2): 203-209.

76. PENEDO T, NUNES WJ, BELTRAO F. Analysis of spatial-temporal orientation in competitive motor performance in rhythmic gymnastics, infantile and pre-infantile. Fitness \& Performance Journal (Online Edition). 2006; 5 (1): 44-49.

77. PEPER E, SCHMID AB. The use of electrodermal biofeedback for peak performance training. Somatics. 1983; 4: 16-18

78. PETKOVIC E. The relation of situational-motor coordination to the competitive success of female gymnasts. Facta Universitatis: Series Physical Education \& Sport. 2004; 2 (1): 25-33.

79. POLISCHUK T. Influence of exhaustion to reliability of basic elements of performance in rhythmic gymnastics. Teoria i Praktika Fiziceskoj Kul'tury. 2001; 11: 07-11.

80. POLISZCZUK T, BRODA D. Somatic constitution and the ability to maintain dynamic body equilibrium in girls practicing rhythmic gymnastics. Pediatry Endocrinol Diabetes Metab. 2010; 16 (2): 94-99.

81. POPOVIC R. The relations among basic and specific motor abilities and successfully adapting of rhythmic-sports gymnastics teaching program. In Sports Medicine Australia, Book of abstracts: 2000 Pre-Olympic Congress: International Congress on Sport Science, Sports Medicine and Physical Education, Brisbane Australia 7-12 September 2000, 210. Australia: Sport Medicine Australia. 2000.

82. POPOVIC R. Performing attitude profiling of musicality in rhythmic gymnastics. In Klisouras, V. (ed.), Pre-Olympic Congress: Proceedings: Volume I. Lectures-orals: sport science through the ages, 6-11 August 2004, 299-300. Thessaloniki, Greece: Aristotle University of Thessaloniki, Department of Physical Education \& Sport Science. 2004.

83. PORTIER H, ARLETTAZ A, LEPANSE B, LECOCQ AM, LABSY Z, COLLOMP K. Energy expenditure in rhythmic gymnastic. Science \& Sports. 2006; 21 (5): 300-302.

84. PURENOVIĆ T, BUBANJ S, POPOVIĆ R, STANKOVIĆ R, BUBANJ R. Comparative Kinematics analysis of different split front leaps. Sport Science. 2010; 3 (1): 13-20.

85. ROMERO B, PALOMINO A, GONZÁLEZ JJ. The Anthropometric Profile of Rhythmic Gymnastics. Apunts: Educació Física i Esports. 2011; 103 (1): 48-55. 
86. RUTKAUSKAITE R. The interaction of training and sport performance in rhythmic gymnastics during competition period. Education. Physical Training. Sport. 2005; 4 (8): 49-55.

87. RUTKAUSKAITE R, SKARBALIUS A. Training and sport performance of the 11-12 year old athletes in rhythmic gymnastics. Education. Physical Training. Sport. 2009; 1 (72): 107-115.

88. RUTKAUSKAITE R, SKARBALIUS A. Interaction of training and performance of 13-14 year old athletes in rhythmic gymnastics. Education. Physical Training. Sport. 2011; 3 (82): 29-36.

89. RUTKAUSKAITE R, SKARBALIUS A. Models and interaction of intensive training and sport performance of 14-15 years old athletes in Rhythmic Gymnastics. Sportas. 2012; 4 (87): 57-64.

90. ŠEBIĆ-ZUHRIĆ L, SMAJLOVIĆ N. Qualitive changes of the motor abilities and stylized movement structures in rhythmic gymnastics under influence of the kinesiology. Homo Sporticus. 2009; 11 (1): 22.

91. SEKULIC D, MILETIC D, RAUSAVLJEVIC N. Knowledge performance or basic clubs technical elements in rhythmic gymnastics. In Koskolou, M. (ed.), European College of Sport Science. Proceedings of the 7th annual congress of the European College of Sport Science. Pashalidis Medical Publisher. Athens, Greece, 24-28 July 2002, 605.

92. SOARES AA. Ginastica ritmica desportiva e dominancia manual interferencia do desempenho da mao nao dominante e da equalizacao do uso de ambas as maos na performance de ginastas destrasral. (Doctoral dissertation). Available from Universidade de Sao Paulo. 1981

93. STEFANOVA D, YAKIMOVA M. The difficulty and the risk factor in the free compositions characteristic components of the Bulgarian school of rhythmic gymnastics. Vaprosi na Fiziceskata Kultura. 1987; 11: 30-37.

94. SUNDGOT-BORGEN J. Eating disorders, energy intake, training volume, and menstrual function in high-level modern rhythmic gymnasts. International Journal of Sport Nutrition. 1996; 6 (2): 100 109.

95. TSIGILIS N, DOUDA H, SOFIADIS N, MERTZANIDOU O. The effect of the induced stimulation of the vestibular system on the ability of balance of rhythmic sports gymnasts and female basketball players, aged 9 to 11. Exercise \& Society Journal of Sport Science. 1998; (19): 69-77.

96. TSOPANI D, DALLAS G, SKORDILIS EK. Competitive state anxiety and performance in young female rhythmic gymnasts. Percept Mot Skills. 2011; 112 (2): 549-560.

97. TSOPANI D, DALLAS G. TASIKA N, TINTO A. The effect of different teaching systems in learning rhythmic gymnastics apparatus motor skills. Science of Gymnastics Journal. 2012; 4 (1): 55-62.

98. VITALI F, SENAREGA D, AMORETTI G. Nutritional behaviours and sports practice: a research on young athletes. Psicologia Dello Sport. 2003; 3 (3): 51-55.

99. WANG A. Devising morphological models for rhythmic gymnasts. Sports Science/Tiyu Kexue. 1989; 9 (2): 39-44.

100. WOLF-CVITAK J, STAROSTA W. Scope of lateral differentiation of movements in selected rhythmic gymnastic exercises performed by participants of Olympic games in Atlanta. Medycyna Sportowa. 2002; 18 (11): 473-484.

101. YI L. Review of the rhythmic gymnastics team of the institute at the 9th national championship. Journal of Chengdu Institute of Physical Education. 2000; 26 (2): 80-82. 